\title{
Association Between Personality Traits Toward Culture Shock Among Indonesian Caregiver in Japan Under Economic Partnership Agreement
}

\author{
Erwin Yektiningsih ${ }^{1 *}$, Norma Risnasari ${ }^{2}$, Endah Tri Wijayanti ${ }^{2}$ \\ ${ }^{I}$ Nursing Program Of STIKes Pamenang, Indonesia \\ ${ }^{2}$ Diploma Nursing Program, Nusantara PGRI Kediri University, Indonesia \\ Corresponding author: erwiny.parefortune@gmail.com
}

\begin{abstract}
Background: Among Indonesian nurses who worked in Japan under Economic Partnership Agreement (EPA). They were placed in hospitals as nurses and nursing homes as caregivers. They experience cross-cultural tend to culture shock because of the personality traits needed socio-cultural to adaptations skills to live new environment.
\end{abstract}

Purpose: This study aimed to increase professionally among Indonesian nurses placement job in Japan with enhancing adequate personality traits for adaptation cross-cultural live and health facility job in Japan that can preventive culture shock.

Methods: This study used a cross-sectional approach with a non-probability sampling method. The population study was 307 among health professionals migration Indonesian in Japan, and obtained a sample of 180 respondents of Indonesian caregiver in nursing home Japan, that passing the National Board Examination (NBE) and have not. Selected using a random sampling technique. The data were collected using questioner. Data analysis used a contingency coefficient.

Results: The results of research culture shock participants were $17 \%$ and normal $83 \%$. This showed study extraversion have a significant association with culture shock ( $\rho$ value $=0$. 042 ) and openness ( $\rho$ value $=0.109)$, conscientiousness ( $\rho$ value $=0.518)$, agreeableness $(\rho$ value $=0.213)$, neuroticism $(\rho$ value $=0.592)$ were not a significant association with culture shock.

Conclusion: The nursing institutions plants to curriculum containing material for increasing nursing resources study cross-cultural skills in an abroad workplace to avoid culture shock who need very good mentally with increase competence of reinforcing positive personality traits.

Keywords: Caregiver, Culture Shock, Japan, Personality Traits. 
Journal Of Nursing Practice

http://thejnp.org

ISSN: 2614-3488 (print); 2614-3496 (online)

Vol.5 No.1. October 2021. Page.146-154

\section{BACKGROUND}

The Japan demographic changes reported population total ages 65 over increased elderly to $23,4 \%$ in 2011. That condition Japan is causing growing problems for nursing care (Mari Kinkawa et al., 2014). With the signing of the bilateral Economic Partnership Agreement (EPA), Japan also began accepting foreign nurse trainees from Indonesia in 2008 occupancy placement Japan to nurses are working as nurses (kanggo-shi) in hospitals and as caregivers (kaigo fukushi-shi) in nursing homes (Sae Tanaka, Hitomi Matsunaga et al., 2016).

Indonesian nurses migrated to work in Japan with Government to Government ( $G$ to G) placement mechanism under the Indonesia Japan Economic Partnership Agreement (IJEPA) which was facilitated by Indonesian Migrant Workers Protection Agency (BP2MI) and Japan International Corporation of Welfare Services (JICWEL) (BP2MI, 2020). Beginning from 2008 until 2019 Indonesian nurses sent to Japan have reached 2,793 people. Those who returned to Indonesia have reached 1,475 people. That can be concluded to Indonesian under IJEPA total was being lived in Japan of 1,318 people. Placement of nurses and caregivers under IJEPA in the last 5 years shows a higher graduation rate than the previous period of $38.2 \%$ (Kurniati Anna et al., 2020).

Personality traits are a psychological component that affects the adjustment of professional workers to work abroad (Huff et al., 2014). Personality traits characterize how a person feels, thinks, and most importantly behaves (Takase et al., 2018). The personality of Immigrant employees who work in new places tend to culture shock, in order to survive new workplaces, they carry out adjusting behaviours that are influenced by combination skill mental and personal abilities (Mahmood \& Burke, 2018). The mental ability component consists of psychological cross-cultural in order to be able to adapt for manage daily life in a new cultural context in a way that can cope with emotional stress, depression, anxiety, and barriers from culture shock (Doki et al., 2018). While the personal abilities of the professional migrants in workers workplace suitable sociocultural adaptation are personality types, work experience, foreign language proficiency (Renand, 2013). which can be aligned with personality traits to control emotions using constructive coping mechanisms of sociocultural adaptation that affect individual behaves tolerantly in interacting in a new place (Yao et al., 2018).

The health professionals migration to a new environment can negatively affect, including mental well-being confusion living in a new country with a different socio-culture and living and working environment can trigger a culture shock condition (Doki et al., 2018). The results Yektiningsih, E et al., (2021) reported among Indonesian nurses working in hospital Japan based on an economic partnership agreement to experience culture shock level a poor of $40 \%$ and moderate of $11 \%$. The current study found among Indonesian worker migrants in Hongkong to experience culture shock level a poor of $72 \%$, moderate of $82,88 \%$ and high of 5,4\% (Iqbal, Muhammad and Verdaningrum, 2016).

Among migrants who experiences culture shock trying to adapt socioculturally by using response coping mechanisms. Culture shock can be treated to indications individuals adapt acculturation responses to the host culture. When the individual fails to adjust, it results in a maladaptive response causes an acculturative stress response (Mahmood \& Burke, 2018). The negative impact of culture shock in everyday life on mental health is depression, anxiety and feelings of helplessness resulting in impaired concentration in learning new cultures, problems solving problems and making decisions. It can cause a decrease in motivation to adapt to new conditions that are likely to become enemies of the host country's citizens, which can lead to defects in interpersonal relationships (Renand, 2013). 


\section{Journal Of Nursing Practice}

http://thejnp.org

ISSN: 2614-3488 (print); 2614-3496 (online)

Vol.5 No.1. October 2021. Page.146-154

The impact of culture shock in the workplace is experiencing physical stress and mental that have a negative impact on motivation, performance, and productivity that causes low-quality human resource competitiveness (Doki et al., 2018). A professional migrant worker decides to return to his home country before the employment contract expires. This phenomenon can be a big loss for the company, considering the cost of sending professionals is not cheap, the loss of market share, and relations with clients and local government officials are not good (Mahmood \& Burke, 2018). A study was conducted to indicate mental problems among Indonesian nurses and care workers to work in Japan under The IJEPA program of $22.5 \%$. Some mental problems have been caused by routine stress (Nugraha, Susiana and Hirano, 2016). General self-efficacy modifies the effect mental problems of stress on burnout in nurses with different personality types. The involvement of personality has been reported in the development of burnout, and some individuals with a certain personality trait are more susceptible to job-related burnout (Yao et al., 2018).

\section{OBJECTIVE}

The objectives of this study are to clarify health professionals migration Indonesian migrate to work in Japan to a cross-cultural adaptation process experiencing culture shock is influenced personality traits. Important nursing competence about positive personality traits are tended to adapt in the workplace abroad to experience could enhance workplace learning. For Indonesians in Japan may enhance a mutual understanding between Indonesian and Japanese health professionals migration, leading to better utilization of human resources.

\section{METHODS}

Research design

This study was conducted a type of descriptive-analytic research with a crosssectional design.

\section{Research participants and location}

The population this study were 307 among health worker Indonesian in Japan under IJEPA Program and obtained a sample of 180 respondents of Indonesian caregiver have been working in Japan nursing home both passing the National Board Examination (NBE) and have not. Random sampling was used to recruit the participants. Inclusion criteria were participants who care giver arrived more 1 years to work in nursing home Japan passed the NBE and who unpassed. The exlusion criteria was incooperative. The independent variable was personality traits. The dependent variable was culture shock

\section{Research instruments}

This study has used two questionnaires including the Basic Traits Inventory (BTI) was used to measure the Big Five personality traits consists of 20 items by focusing personality traits on big five scale (Openness, conscientiousness, extraversion, agreeableness, neuroticism). The answer choices of the PTQ in this study used a Likert-type scale poor, average, good (Hee, 2014). The BTI has been tested for reliability and validity, and the Cronbach's alpha of 0.915 , with a sensitivity ranged from 0.504 to 0.950 .

The Culture Shock Questionnaire (CSQ) consists of 12 items by focusing on two major areas: the core culture shock items component and the interpersonal stress items. The answer choices of the CSQ in this study used a Likert-type scale poor, average, good (David Bardwell Mumford, 2000). The Indonesian-language version of the CSQ has been tested for reliability and validity, and the Cronbach's alpha of 0.906 , with a sensitivity ranged from 0.461 to 0.869 . 


\section{Journal Of Nursing Practice}

http://thejnp.org

\section{Data collection and ethical consideration}

The researcher permited and coordinated to Indonesian Migrant Workers Protection Agency (BP2MI) to obtain respondent data in accordance with the researchers' criteria. The explanation of the terms and conditions of the study and informed consent for study participation was obtained. All respondents were assured of the voluntary and confidential nature of the study. A total of 32 questionnaires items were distributed online in link google during October to December 2020. The questionnaire was set up with a default one response per respondent to avoid any duplicate responses. The BP2MI has given notification of the complete a questionnaire was automatically sent to the respondent's email of private message address. Prior to the data collection, approval to conduct the study was obtained from the ethics committees at the Health Research Ethics Commission of the Faculty of Medicine, Universitas Brawijaya (Reference No.141/EC/KEPK-S2). The ethical requirements and respondent rights have been fulfilled throughout the research process to collect the data online in google form link was not cause harm and was not disturbed.

Data analysis

This research was conducted with IBM SPSS Statistics 24. The analysis of the research used univariate analysis of frequency distribution, then the bivariate analysis of contingency coefficient with a significance level of $\rho<0.05$.

\section{RESULTS}

Table 1 saw the distribution of data dominant of personality traits and culture shock level study participants. The average dominant of personality traits of agreeableness study participants were of $84(47 \%)$. Then the average study participants were not culture shock or normal level of $150(83 \%)$.

Table 1. Respondents were dominant of personality traits and culture shock $(n=180)$

\begin{tabular}{|c|c|c|}
\hline Variable & $\mathbf{n}$ & $\%$ \\
\hline \multicolumn{3}{|l|}{ Personality traits } \\
\hline Openness & 56 & 31 \\
\hline Conscientiousness & 18 & 10 \\
\hline Extraversion & 8 & 4 \\
\hline Agreeableness & 84 & 47 \\
\hline Neuroticism & 14 & 8 \\
\hline \multicolumn{3}{|l|}{ Culture shock level } \\
\hline Normal & 150 & 83 \\
\hline Culture shock & 30 & 17 \\
\hline
\end{tabular}

Table 2 presents the mean of predictor variables between personality traits toward culture shock. This showed study extraversion have a significant association with culture shock ( $\rho$ value $=0.042$ ) that indicated an association between variables. The results of further analysis related to extraversion and culture shock level of the normal category had extrovert traits participants of $144(80 \%)$. Personality traits of openness ( $\rho$ value $=0.109)$, conscientiousness ( $\rho$ value $=0.518)$, agreeableness $(\rho$ value $=0.213)$, neuroticism $(\rho$ value $=0.592)$ were not a significant association with culture shock. 


\section{Journal Of Nursing Practice}

http://thejnp.org

ISSN: 2614-3488 (print); 2614-3496 (online)

Vol.5 No.1. October 2021. Page.146-154

Table 2. Association between personality traits toward culture shock $(\mathrm{n}=180)$

\begin{tabular}{|c|c|c|c|c|c|c|c|}
\hline \multirow{3}{*}{ Personality traits } & \multicolumn{4}{|c|}{ Culture shock level } & \multirow{2}{*}{\multicolumn{2}{|c|}{ Total }} & \multirow{3}{*}{$\begin{array}{c}\rho \\
\text { value }\end{array}$} \\
\hline & \multicolumn{2}{|c|}{ Normal } & \multicolumn{2}{|c|}{$\begin{array}{l}\text { Culture } \\
\text { shock }\end{array}$} & & & \\
\hline & $\mathbf{n}$ & $\%$ & $\mathbf{n}$ & $\%$ & $\mathbf{n}$ & $\%$ & \\
\hline \multicolumn{8}{|l|}{ Openness } \\
\hline Inovatif & 142 & 79 & 26 & 14 & 168 & 93 & 0.109 \\
\hline Konvensional & 8 & 5 & 4 & 2 & 12 & 7 & \\
\hline \multicolumn{8}{|l|}{ Conscientiousness } \\
\hline Positive & 144 & 80 & 28 & 16 & 172 & 96 & 0.518 \\
\hline Negative & 6 & 3 & 2 & 1 & 8 & 4 & \\
\hline \multicolumn{8}{|l|}{ Extraversion } \\
\hline Ekstrovert & 144 & 80 & 26 & 14 & 170 & 94 & 0.042 \\
\hline Introvert & 6 & 3 & 4 & 2 & 10 & 6 & \\
\hline \multicolumn{8}{|l|}{ Agreeableness } \\
\hline Kooperative & 140 & 78 & 26 & 14 & 166 & 92 & 0.213 \\
\hline Inkooperative & 10 & 6 & 4 & 2 & 14 & 8 & \\
\hline \multicolumn{8}{|l|}{ Neuroticism } \\
\hline Emosional positive & 124 & 69 & 26 & 14 & 150 & 83 & 0.592 \\
\hline Emosional negative & 26 & 14 & 5 & 3 & 30 & 17 & \\
\hline
\end{tabular}

Table 3 saw the distribution of data characteristic of the study participants. The average gender of study participants were female of $126(70 \%)$, with subjects were single status of $112(62 \%)$. The average bachelor of nursing education study participants were of $96(53 \%)$. The average religion study participants were Islam of $114(63 \%)$. The average study participant did not pass NBE of $152(85 \%)$.

Table 3. Characteristics respondents $(\mathrm{n}=180)$

\begin{tabular}{lrr}
\hline \multicolumn{1}{c}{ Characteristic } & n & \% \\
\hline Gender & & \\
Female & 126 & 70 \\
$\quad$ Male & 54 & 30 \\
\hline Religion & & \\
$\quad$ Islam & 114 & 63 \\
Protestant & 40 & 22 \\
Catholic & 8 & 5 \\
$\quad$ Hindu & 18 & 10 \\
\hline Status & & \\
$\quad$ Single & 112 & 62 \\
$\quad$ Married & 60 & 33 \\
$\quad$ Widower/ widow & 8 & 5 \\
\hline Less 2 years job experience in medical & & \\
facility & & \\
$\quad$ No & 117 & 65 \\
$\quad$ Yes & 63 & 35 \\
\hline Passed NBE & & \\
$\quad$ No & 152 & 85
\end{tabular}


Journal Of Nursing Practice

http://thejnp.org

ISSN: 2614-3488 (print); 2614-3496 (online)

Vol.5 No.1. October 2021. Page.146-154

\begin{tabular}{lll}
\hline Yes & 28 & 15 \\
\hline Education Nursing & & \\
Associate's degree & 84 & 47 \\
Bachelor & 96 & 53 \\
\hline
\end{tabular}

\section{DISCUSSION}

This research identified the average normal culture shock of $83 \%$ care giver working nursing home in Japan. The results Sae Tanaka, Hitomi Matsunaga et al., (2016) reported results a comparative study to the cross-cultural tolerance between Indonesian immigrants of travellers, students, internship, health workers who come to Japan, that the health professional under IJEPA have the highest ability to tolerate cross-cultural to adapt to culture shock. So that they acculturation living in Japan because cross-cultural tolerance skills had been related relevant by graduated from a nursing college or vocational school background with health services job experience history, they have received Japanese culture and language training. That appropriate this result study All respondents had education nursing were associate's degree of $47 \%$ and bachelor of $43 \%$, then experience in medical facility of $35 \%$, as indicated in tabel 3 .

The migrants experience acculturation which cultural tolerance process to a new culture develops relationships with the host culture and maintains immigrant native culture (Hariyadi, 2013). Migration adapting to individual duration time contact with host culture stays to improve cross-cultural tolerance competency that can reduce stressor precipitation (Doki et al., 2018). The health professionals under IJEPA experienced reasonable difficulties due to the long duration of time of more than one year in Japan which tended to be able to study actual competency sociocultural adaptation (Nugraha \& Ohara-Hirano, 2016). The immigrants culture native were contact host culture stays in long periods that associated increasing psychological adjustment which can be tolerance competency enhancement social support contact quality for communication cross-cultural to better understand each other (Hatanaka, Kaori and Tanaka, 2016).

This study identified the average personality traits dominant of agreeableness, that tends to be submissive and obedient to the rules in the workplace. The agreeableness types consist cooperative type is easy to agree with, trusts others and the uncooperative type is difficult to agree with because it focuses on one's own needs (Takase et al., 2018). That appropriate these result study respondents had cooperative of $78 \%$ and uncooperative of $14 \%$, as indicated in table 2 .

The current study found that the culture shock predictors are associated with type extraversion personality traits. Extraversion is a personality type that assesses the quantity and intensity of interpersonal interactions, the level of need for support in carrying out activities, and the ability to feel happy (Takase et al., 2018). Type extraversion personality traits are one of a psychological component that affects the adjustment of professional workers to work abroad (Renand, 2013). Two types of extraversion personality traits, namely extroverts tend to be friendly, open, likes many friends and introverted types tend to be closed, like to be alone (Jelavic Sanda Rasic., 2021). An extrovert is emotional stability flexibility and social initiative open-mindedness (Yao et al., 2018). Emotional stability flexibility personality personals will assume situational conditions of cultural differences in abroad workplace can pose a threat aspect so culture shock as a stress trigger. Meanwhile, the initiative open-mindedness personality type person has an open mind tends to occur to adaptive responses to cultural differences situations, so that they feel challenging aspects for career development working abroad (van der Zee \& van Oudenhoven, 2013). That 


\section{Journal Of Nursing Practice}

http://thejnp.org

ISSN: 2614-3488 (print); 2614-3496 (online)

Vol.5 No.1. October 2021. Page.146-154

appropriate these result study respondents had culture shock level of the normal category had extrovert traits participants average of $80 \%$, as indicated in table 2 .

The current study foud culture shock was not associated with personality traits kind of openness, conscientiousness, agreeableness and neuroticism, that are relevant in intercultural competence that can reduce stressor precipitation culture shock. Openness is a dimension for knowing interest, conscientiousness is a dimension of motivating ability to achieve goals, agreeableness is a dimension of obeying rules and neuroticism is a dimension of controlling emotions (Takase et al., 2018). Obtained from various studies, there are various personality trait triggers culture shock immigrant. The current study found Shaifa \& Supriyadi (2013) study results personality types capable of adaptive adjustment to culture shock were agreeableness and openness. While the conscientiousness, extraversion, and neuroticism personality types were maladaptive so they tend to experience culture shock. The current study found Novikova et al., (2017) reported 388 foreign students studied in Russian Universities. The research results on personality types that had Intercultural competence so that they can adapt to culture shock were openness, conscientiousness, extraversion, agreeableness. While personality traits difficult to adapt occur culture shock was neuroticism.

Personality traits are a psychological component that affects the adjustment of professional workers to work abroad (Renand, 2013). Each individual has a unique personality type that can arise from relatively permanent character patterns and unique characters that have consistency and uniqueness in individual behavior (Takase et al., 2018). Each individual has cognition, affect, and different ways of behaving in different situations and times. Although the majority of individuals in a country have almost similar values so that the behaviour, mindset, and morals of the people in that country look the same, each individual still has his own uniqueness (Jelavic Sanda Rasic, Aleksic Anna, 2021).

Worker Profesional immigrants have different adaptation strategies depending on the adjustment of an expatriate to the host culture. Cross-cultural adaptation can be understood in the social learning paradigm and refers to how well individuals are able to manage daily life in a host cultural context (Harlinda, 2018). One of the personality theories used to explain a person's personality traits is the big five personalities, there are five dimensions of Openness, Conscientiousness, Extraversion, Agreeableness, Neuroticism(Shaifa \& Supriyadi, 2013).

\section{CONCLUSION}

Based on the results of this study, it can be concluded Indonesian immigrant caregivers professionals in Japan, who have culture shock $17 \%$. This study of result trigger a culture shock was caused to a type of extraversion personality traits that attend to ability interpersonal maladaptive. The Personality traits, such as openness, conscientiousness, agreeableness and neuroticism tend to be submissive and obedient to adapt in workplace abroad to experience could enhance workplace learning and nursing competence. Average this study result kind dominant of agreeableness personality traits than skill tendency to comply with workplace rules. Hopefully, the results of this study can be used nursing institutions curriculum containing material for increasing nursing resources. The graduate nurses for working abroad are study cross-cultural skills who sociocultural adaptations skills in an abroad working environment to avoid culture shock who need very good mentally with increase competence of reinforcing positive personality traits and creating an environment that matches nurses' personality traits are necessary in order to facilitate workplace learning and to improve nurses' feeling of competence. 


\section{Journal Of Nursing Practice}

http://thejnp.org

ISSN: 2614-3488 (print); 2614-3496 (online)

Vol.5 No.1. October 2021. Page.146-154

ACKNOWLEDGMENT

I would also like to thank BP2MI has helped collect data online and all the respondents who took the time to participate

\section{CONFLICTS OF INTEREST}

The authors declare that there is not conflict of interest.

\section{REFERENCES}

BP2MI. (2020). 5 skema penempatan pekerja migran Indonesia. http://www.bnp2tki.go.id

David Bardwell Mumford. (2000). Culture Shock among Young British Volunteers Working Abroad: Predictors, Risk Factors and Outcome. Transcultural Psychiatry, 37(1), 73-87.

Doki, S., Sasahara, S., \& Matsuzaki, I. (2018). Stress of working abroad: a systematic review. International Archives of Occupational and Environmental Health, 91(7), 767-784. https://doi.org/10.1007/s00420-018-1333-4

Hariyadi, E. (2013). Tuntutlah ilmu di negeri sakura: kuliah di Jepang dalam persepsi muslim Indonesia alumni Jepang. Thaqafiyyat, 14(1), 28-57. http://ejournal.uinsuka.ac.id/adab/thaqafiyyat/index

Harlinda, K. and H. S. (2018). Analisis strategi adaptasi ekspatriet dalam mengatasi culture shock. Jurnal Administrasi Bisnis (JAB), 59(1), 33-40. administrasibisnis.studentjournal.ub.ac.id

Hatanaka, Kaori and Tanaka, T. (2016). Cross-cultural factors that influence adjustments of foreign care workers in Japan: towards a three-layered structural model. International Journal of Health and Life-Sciences, 2(3), 1-17. https://doi.org/https://dx.doi.org/10.20319/lijhls.2016.23.0117

Hee, O. C. (2014). Validity and reliability of the big five personality traits scale in Malaysia. International Journal of Innovation and Applied Studies ISSN, 5(4), 2028-9324. http://www.ijias.issr-journals.org/

Huff, K. C., Song, P., \& Gresch, E. B. (2014). International Journal of Intercultural Relations Cultural intelligence, personality, and cross-cultural adjustment: A study of expatriates in Japan. International Journal of Intercultural Relations, 38, 151- 157. https://doi.org/http://dx.doi.org/10.1016/j.ijintrel.2013.08.005

Iqbal, Muhammad and Verdaningrum, A. (2016). Pengaruh culture shock dan adversity quotient terhadap kepuasan kerja tenaga kerja Indonesia (TKI) di Hongkong. Jurnal Kajian Wilayah, 7(2), 101-112.

Jelavic Sanda Rasic, Aleksic Anna, B. I. N. (2021). Behind the curtain : workplace incivility - individual actors in cultural settings. Sustainability, 13(1249), 1-14. https://doi.org/https://doi.org/10.3390/su13031249

Kurniati Anna, Astari Lita Dwi, Efendi Ferry, Haryanto Joni, Indarwati Retno, Has Eka Mishbahatul, Ulfiana Elida, Puspitasari Ias Tarina, Muryani Made, Dianawatisari Heni, Rani Ifrani Yuan Khaulaha, K. L. D. (2020). Analisis kebijakan pemenuhan pasar kerja tenaga kesehatan di tingkat global. Kemenkes RI.

Mahmood, H., \& Burke, M. G. (2018). An analysis of acculturative stress, sociocultural adaptation, and satisfaction among international students. Global Perspectives on International Student Experiences in Higher Education: Tensions and Issues, 63, 109121. https://doi.org/10.4324/9781315113456

Mari Kinkawa, Elsi D. Hapsari, Eni N. Agustini, Sayaka Kotera, H. M. (2014). A change of Japanese nurses' view of Indonesian nursing candidates based on an Economic 


\section{Journal Of Nursing Practice}

http://thejnp.org

ISSN: 2614-3488 (print); 2614-3496 (online)

Vol.5 No.1. October 2021. Page.146-154

Partnership Agreement. Bullet in of Health Sciences Kobe, 30, 21-33. https://doi.org/10.24546/81008793

Novikova, I. A., Gridunova, M. V., Novikov, A. L., Shlyakhta, D. A., Vorobyeva, A. A., \& Zamaldinova, G. N. (2017). "Big five" factors and intercultural sensitivity in Russian University Students. Man in India, 97(16), 185-197.

Nugraha, S., \& Ohara-Hirano, Y. (2016). The Mental Health Predictors of Indonesian EPA Nurses and Certified Care Worker Candidates in Japan. Japanese Psychological Research, 58(1), 85-96. https://doi.org/10.1111/jpr.12100

Renand, J. R. and F. (2013). Culture shock in a global world: factors affecting culture shock experienced by expatriates in Oman and Omani expatriates abroad. International Journal of Business and Management, 8(13), 144-160. https://doi.org/10.5539/ijbm.v8n13p144

Sae Tanaka, Hitomi Matsunaga, N. N., Shibayama, K., Ishibashi, A., Akinaga, K., Kakihara, N., Fukuyama, Y., \& Shinchi, K. (2016). Factors related to Japanese Nurses ' Tolerance Toward Indonesian Nurse Trainees. Asian Journal of Human Services, 11, 1-17. https://doi.org/http://dx.doi.org/10.14391/ajhs.11.1

Shaifa, D., \& Supriyadi, S. (2013). Hubungan Dimensi Kepribadian The Big Five Personality dengan Penyesuaian Diri Mahasiswa Asing di Universitas Udayana. $\begin{array}{llll}\text { Jurnal Psikologi Udayana, } & \text { 72-83. }\end{array}$ https://doi.org/10.24843/jpu.2013.v01.i01.p08

Takase, M., Yamamoto, M., \& Sato, Y. (2018). Effects of nurses' personality traits and their environmental characteristics on their workplace learning and nursing competence. Japan Journal OfNursing Science, 15, 167-180. https://doi.org/10.1111/jjns.12180

Van der Zee, K., \& van Oudenhoven, J. P. (2013). Culture shock or challenge? the role of personality as a determinant of intercultural competence. Journal of Cross-Cultural Psychology, 44(6), 928-940. https://doi.org/10.1177/0022022113493138

Yao, Y., Zhao, S., Gao, X., An, Z., Wang, S., Li, H., Li, Y., Gao, L., Lu, L., \& Dong, Z. (2018). General self-efficacy modifies the effect of stress on burnout in nurses with different personality types. BMC Health Services Research, 18(667), 1-9. https://doi.org/https://doi.org/10.1186/s12913-018-3478-y

Yektiningsih, E., Astari, A. M., \& Utami, Y. W. (2021). A correlation between working environment and job experience toward culture shock among Indonesian nurses in Japan. Jurnal Ners, 16(1), 1-9. https://doi.org/http://dx.doi.org/10.20473/jn.v16i1.23284 